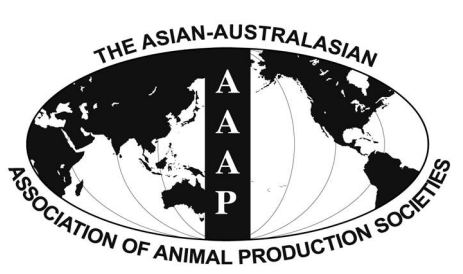

Open Access

Asian Australas. J. Anim. Sci.

Vol. 29, No. 2 : 159-169 February 2016

http://dx.doi.org/10.5713/ajas.15.0681

Www.ajas.info

pISSN 1011-2367 elSSN 1976-5517

\title{
The Physiological Suppressing Factors of Dry Forage Intake and the Cause of Water Intake Following Dry Forage Feeding in Goats - A Review
}

\author{
Katsunori Sunagawa* and Itsuki Nagamine \\ Faculty of Agriculture, University of the Ryukyus, Okinawa 903-0213, Japan
}

\begin{abstract}
The goats raised in the barn are usually fed on fresh grass. As dry forage can be stored for long periods in large amounts, dry forage feeding makes it possible to feed large numbers of goats in barns. This review explains the physiological factors involved in suppressing dry forage intake and the cause of drinking following dry forage feeding. Ruminants consume an enormous amount of dry forage in a short time. Eating rates of dry forage rapidly decreased in the first 40 min of feeding and subsequently declined gradually to low states in the remaining time of the feeding period. Saliva in large-type goats is secreted in large volume during the first hour after the commencement of dry forage feeding. It was elucidated that the marked suppression of dry forage intake during the first hour was caused by a feeding-induced hypovolemia and the loss of $\mathrm{NaHCO}_{3}$ due to excessive salivation during the initial stages of dry forage feeding. On the other hand, it was indicated that the marked decrease in feed intake observed in the second hour of the $2 \mathrm{~h}$ feeding period was related to ruminal distension caused by the feed consumed and the copious amount of saliva secreted during dry forage feeding. In addition, results indicate that the marked decreases in dry forage intake after 40 min of feeding are caused by increases in plasma osmolality and subsequent thirst sensations produced by dry forage feeding. After 40 min of the $2 \mathrm{~h}$ dry forage feeding period, the feed salt content is absorbed into the rumen and plasma osmolality increases. The combined effects of ruminal distension and increased plasma osmolality accounted for $77.6 \%$ of the suppression of dry forage intake 40 min after the start of dry forage feeding. The results indicate that ruminal distension and increased plasma osmolality are the main physiological factors in suppression of dry forage intake in large-type goats. There was very little drinking behavior observed during the first hour of the $2 \mathrm{~h}$ feeding period most water consumption occurring in the second hour. The cause of this thirst sensation during the second hour of dry forage feeding period was not hypovolemia brought about by excessive salivation, but rather increases in plasma osmolality due to the ruminal absorption of salt from the consumed feed. This suggests the water intake following dry forage feeding is determined by the level of salt content in the feed. (Key Words: Physiological Controlling Factors, Excessive Salivation, Plasma Osmolality, Dry Forage Intake, Water Intake, Goats)
\end{abstract}

\section{INTRODUCTION}

Goats raised in barns are usually fed on fresh grass. When fresh forage is dried, it can be stored for long periods in large amounts. This makes it possible to feed large numbers of ruminants. Moreover, dried forage makes feeding management easier for farmers in times of inclement weather when fresh forage cannot be obtained. The load placed on ruminants through dry forage feeding, however, is not clear.

\footnotetext{
* Corresponding Author: Katsunori Sunagawa. Tel: +81-98-8958798, Fax: +81-98-895-8734, E-mail: b986094@agr.u-ryukyu.ac.jp Submitted Aug. 17, 2015; Revised Sept. 22, 2015; Accepted Oct. 17, 2015
}

Dry forage has very low water content, is bulky, and has low energy levels. Because of these factors, ruminants raised on dry forage eat large volumes at one time in order to satisfy their nutritional requirements of maintenance and production levels. Therefore, studies of the effects of rumen fill on silage and hay intake in cows and sheep have been carried out as the part of research on factors regulating dry forage intake in ruminants (Hidari, 1981). Campling and Balch (1961) reported that feed intake was decreased when a balloon was inserted into the rumen and inflated with water in cows fed on hay or silage. In the rumen of ruminants, microbial fermentation is responsible for the production of large amounts of volatile fatty acids (VFA) 
such as acetate, propionate, and butyrate. Approximately $70 \%$ of energy consumption in ruminants is provided by the combustion of VFA such as acetate, propionate, n-butyrate, and $\beta$-hydroxybutyrate (Annison and Armstrong, 1970). This is a major difference between ruminants and monogastric animals whose main energy source is glucose. Based on this, the effects of intraruminal infusion of acetate, propionate and n-butyrate on silage and hay intake were investigated in sheep (Baile et al., 1969; Baile and Forbes, 1974). The aim of the research was to clarify whether or not the acetic, propionic, and n-butyric acids produced in the rumen actually control feed intake. Because the infusion of free acids causes irritation of the rumen wall with pain, VFA sodium salts were used as a substitute for free acids. It was reported that dry forage intake was only suppressed when the intraruminal infusion of sodium acetate, sodium propionate and sodium butyrate caused ruminal fluid concentrations of sodium salts to markedly exceed physiological levels (Forbes, 1995). On the other hand, Grovum (1995) reported that when the same dose of hyperosmotic sodium chloride, polyethylene glycol-400 (PEG), sodium acetate or sodium propionate was infused intraruminally to increase ruminal fluid osmolality in sheep, it resulted in the same-sized decrease in intake of alfalfa pellets. In other words, the suppression of dry forage intake was not caused by VFA but rather by the sodium that combined with the VFA which brought about an increase in ruminal fluid osmolality (Grovum, 1995).

Until now, the majority of studies on the control mechanisms of feed intake in ruminants as well as in monogastric animals were conducted under normal feeding conditions (NFC) whereby feed boluses were allowed to enter the stomach. Anil et al. (1993) reported that in cows, the amount of dry forage or silage intake was not decreased unless the physiological range was exceeded by the volume of water in the balloon inserted in the rumen and by increases in ruminal fluid osmolality. In the experiments (Campling and Balch, 1961; Anil et al., 1993) in which a balloon was inserted into the rumen and filled with water, it is unclear as to how the volume of water was determined to fill the balloon. Consequently, it is not clear whether the ruminal distension or the increased ruminal fluid osmolality produced by feed boluses entering the rumen during dry forage feeding were the main physiological suppressing factors on dry forage intake in ruminants.

In countries such as Japan where ruminants are raised in barns, most farmers feed their livestock a diet of dry forage twice a day. In NFC when goats were fed on dry forage for $2 \mathrm{~h}$ twice daily, irrespective of whether drinking water was supplied (Nagamine et al., 2003; Sunagawa et al., 2003; 2008 ) or withheld (Sunagawa et al., 2002; 2007) during feeding, eating rates rapidly decreased in the first 30 or 40 min of feeding and were subsequently reduced to very low rates for the reminder of the $2 \mathrm{~h}$ feeding period. The low eating rates mean that dry forage intake significantly decreased. Sunagawa et al. $(2002 ; 2003 ; 2007)$ reported that a suppression of dry forage intake during the early stages of feeding was partly caused by feeding-induced hypovolemia, which was produced by the accelerated secretion of parotid saliva. Under NFC, ruminal distension, ruminal fluid osmolality, plasma osmolality and thirst levels all increased at the same time during the second hour of the $2 \mathrm{~h}$ dry forage feeding period. It was difficult, therefore, to clarify which factors are mainly responsible for the control of feed intake during dry forage feeding in ruminants. In the experiments of Thang et al. (2010; 2011a,b; 2012a,b), the factors that are presumed to be responsible for the control of dry forage intake were separated in esophageal-fistulated large-type goats and researched individually under sham feeding conditions (SFC). It was clarified that in large-type goats fed on dry forage for $2 \mathrm{~h}$ twice daily, increases in ruminal distension, plasma osmolality and subsequent thirst sensations that occurred $40 \mathrm{~min}$ after the start of dry forage feeding were the main physiological factors in the marked suppression of feed intake (Thang et al., 2010; 2011a,b; 2012a,b).

Dry forage feeding makes it possible to raise bigger herds of ruminants in barn conditions. Despite this, until now, the physiological factors involved in dry forage intake have remained unclear. The authors undertook research to separately identify the individual physiological factors involved in controlling dry forage intake in large-type goats and then clarify the quantitative suppression effect of each factor. This review explains the physiological factors involved in suppressing dry forage intake and those responsible for drinking behavior following dry forage feeding.

\section{Hypovolemia and the loss of $\mathrm{NaHCO}_{3}$ caused by excessive salivation during the initial stages of dry forage feeding}

Saliva in ruminants is secreted in large volumes during dry forage feeding (Sato, 1975; Sunagawa et al., 2003). Ruminant saliva is mainly composed of fluid, mucin and $\mathrm{NaHCO}_{3}$. The fluid and mucin in saliva act as a lubricant in the mouth and esophagus and assist in the mastication, swallowing, remastication and reswallowing of dry forage. Mucin is also a growth factor for ruminal bacteria (Liu et al., 2005). While the major part of electrolytes in the saliva of non-ruminants is $\mathrm{NaCl}$, the major component in saliva of ruminants is $\mathrm{NaHCO}_{3}$ (Argenzio, 1984). $\mathrm{NaHCO}_{3}$ in saliva also acts as an alkali and serves to buffer the decrease in the $\mathrm{pH}$ of ruminal fluid due to the VFA production of microbial fermentation in the rumen. Absorption rates of VFA in ruminal wall are accelerated by saponification of fatty acids with $\mathrm{NaHCO}_{3}$ (Oshio and Tahata, 1984). In this way, saliva 
plays an important role in feeding of dry forage and maintaining continuous ruminal microorganisms' fermentation.

Saliva is produced using plasma components. Therefore, sheep and large-type goats eating dry forage secrete large quantities $(3,998 \pm 327.27 \mathrm{~g} / 2 \mathrm{~h}$, Thang et al., 2011a) of saliva (Stacy and Warner, 1966; Sunagawa et al., 2003), which decreases plasma volume (a fall of 15\%) during initial stages of dry forage feeding (Blair-West and Brook, 1969). During dry forage feeding, plasma $\mathrm{HCO}_{3}{ }^{-}$as well as $\mathrm{pH}$ also remarkably decreases due to loss of $\mathrm{NaHCO}_{3}$ from the blood via the saliva into the rumen (Sasaki et al., 1974). The decreased plasma volume (hypovolemia) activates the renin-angiotensin system, and stimulates anti-diuretic hormone $(\mathrm{ADH})$ secretion, and decreases urine flow, $\mathrm{Na}^{+}$, $\mathrm{K}^{+}, \mathrm{HCO}_{3}{ }^{-}$and $\mathrm{HPO}_{4}{ }^{--}$(and $\mathrm{H}_{2} \mathrm{PO}_{4}{ }^{-}$) excretion (Blair-West and Brook, 1969; Sasaki et al., 1974; Sasaki et al., 1975; Figures 1 and 2). These changes in the acid-base status and body fluid metabolism are incurred as an accompaniment to

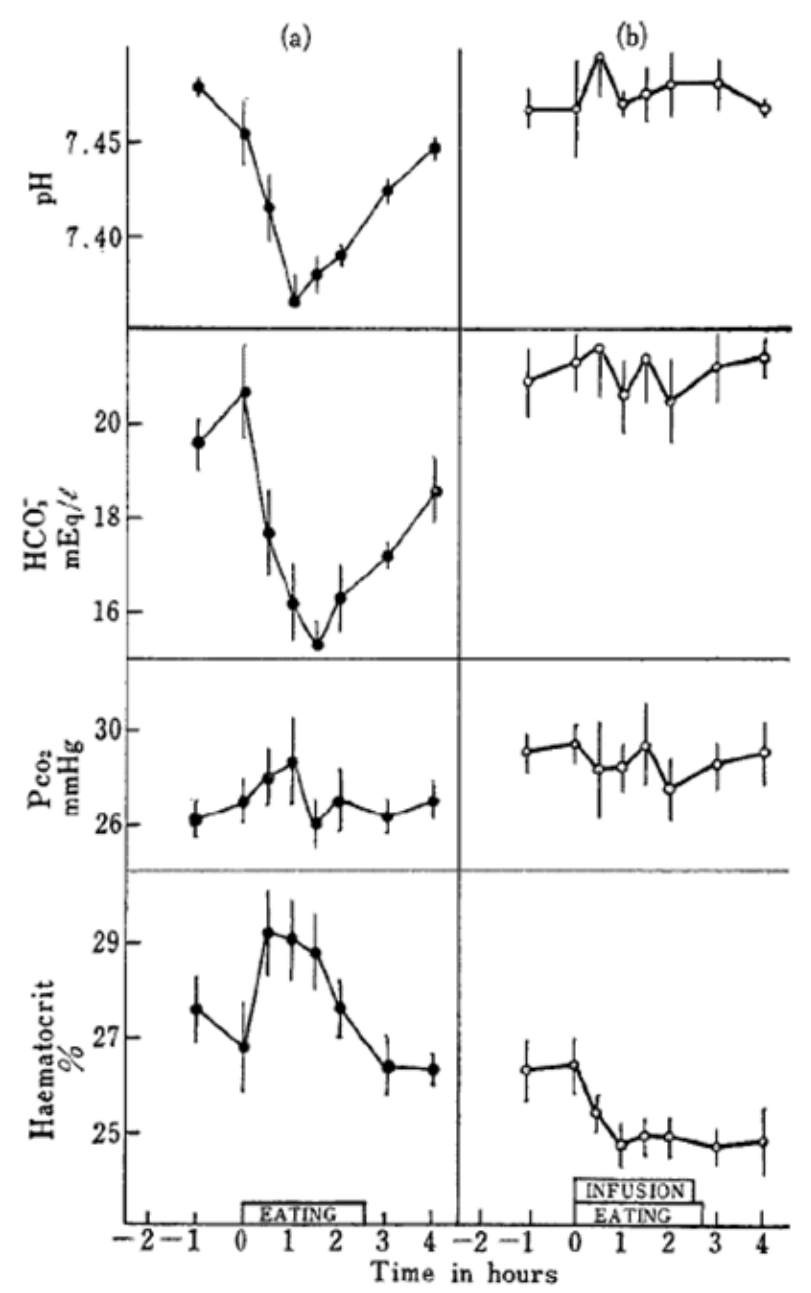

Figure 1. (a) Changes in acid-base status of blood during eating (n $=6, \mathrm{~m} \pm$ standard error), (b) effect of intravenous infusion of artificial saliva on blood acid-base status during eating $(\mathrm{n}=9, \mathrm{~m} \pm$ standard error) (Sasaki et al., 1 975).

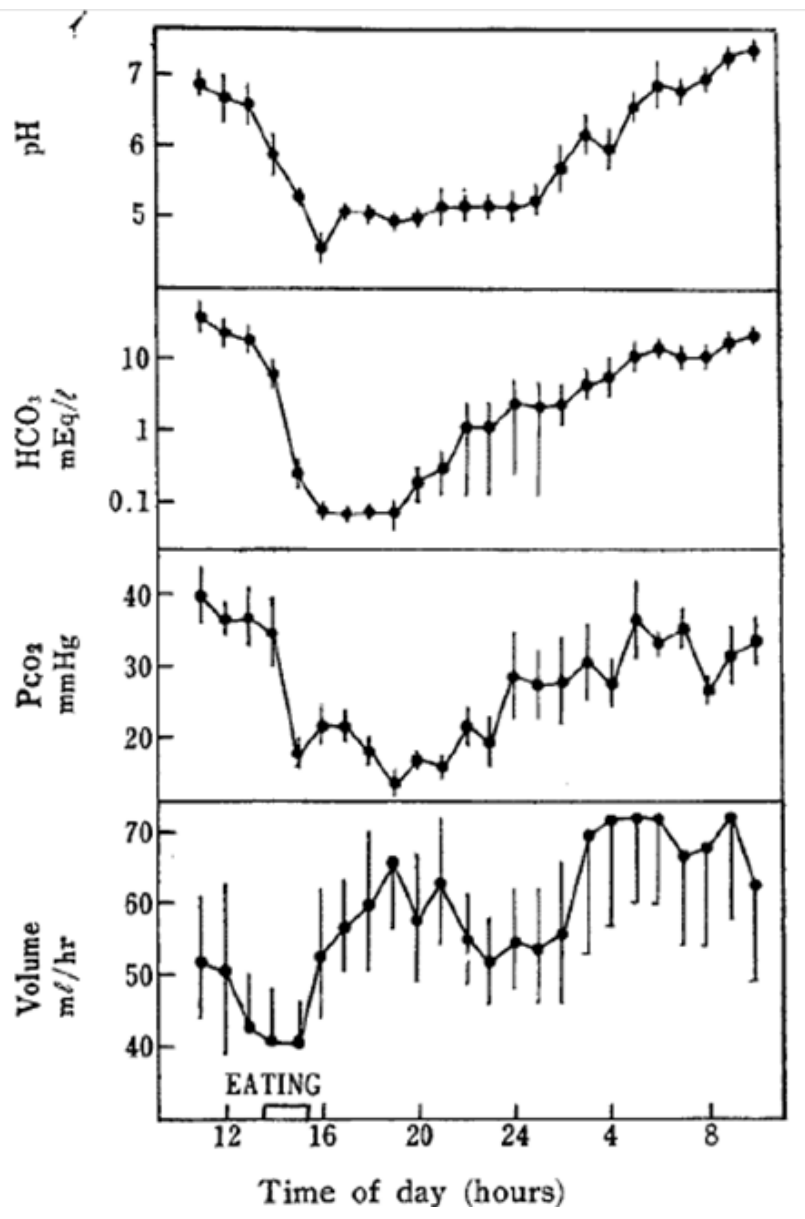

Figure 2. Twenty-four hour changes in $\mathrm{pH}, \mathrm{HCO}_{3}{ }^{-}, \mathrm{P}_{\mathrm{CO} 2}$, and volume of urine of fed sheep. Each point represents mean of twelve trials with standard error (Sasaki et al., 1974).

the intense stimulation to salivary secretion with dry forage feeding. The reabsorption through the rumen wall of salivary components that temporarily move to the rumen slowly returns the body to pre-feeding levels (Sasaki et al., 1974).

A physiological suppression of dry forage intake caused by hypovolemia (decreased plasma volume) and the loss of $\mathrm{NaHCO}_{3}$ during the initial stages of dry forage feeding

It was investigated whether or not the loss of $\mathrm{NaHCO}_{3}$ from the blood and hypovolemia brought about by dry forage feeding actually depress dry forage intake in goats under free drinking conditions (Sunagawa et al., 2008). The experiment consisted of three treatments (non-infusion control: NI, intravenous infusion of artificial saliva: ASI, intravenous infusion of mannitol solution: MI). All treatments in the experiment were carried out under free drinking conditions. In the NI control, a solution was not infused. In the ASI treatment, intravenous infusion of artificial saliva was initiated $2 \mathrm{~h}$ before feeding and was continued for a total of $3 \mathrm{~h}$ concluding $1 \mathrm{~h}$ after the 
commencement of feeding period. In the MI treatment, mannitol solution was infused to replenish only water lost from the blood in the form of saliva. The hematocrit (packed cell volume percentage) and plasma total protein concentrations during feeding in the NI control were observed to be higher than pre-feeding levels (Figure 3). This indicated that dry forage feeding-induced hypovolemia was caused by the accelerated secretion of saliva during the initial stages of feeding in freely drinking

large-type goats. Increases in hematocrit and plasma total protein concentrations due to dry forage feeding were significantly suppressed by the ASI treatment. While hematocrit during feeding in the MI treatment was
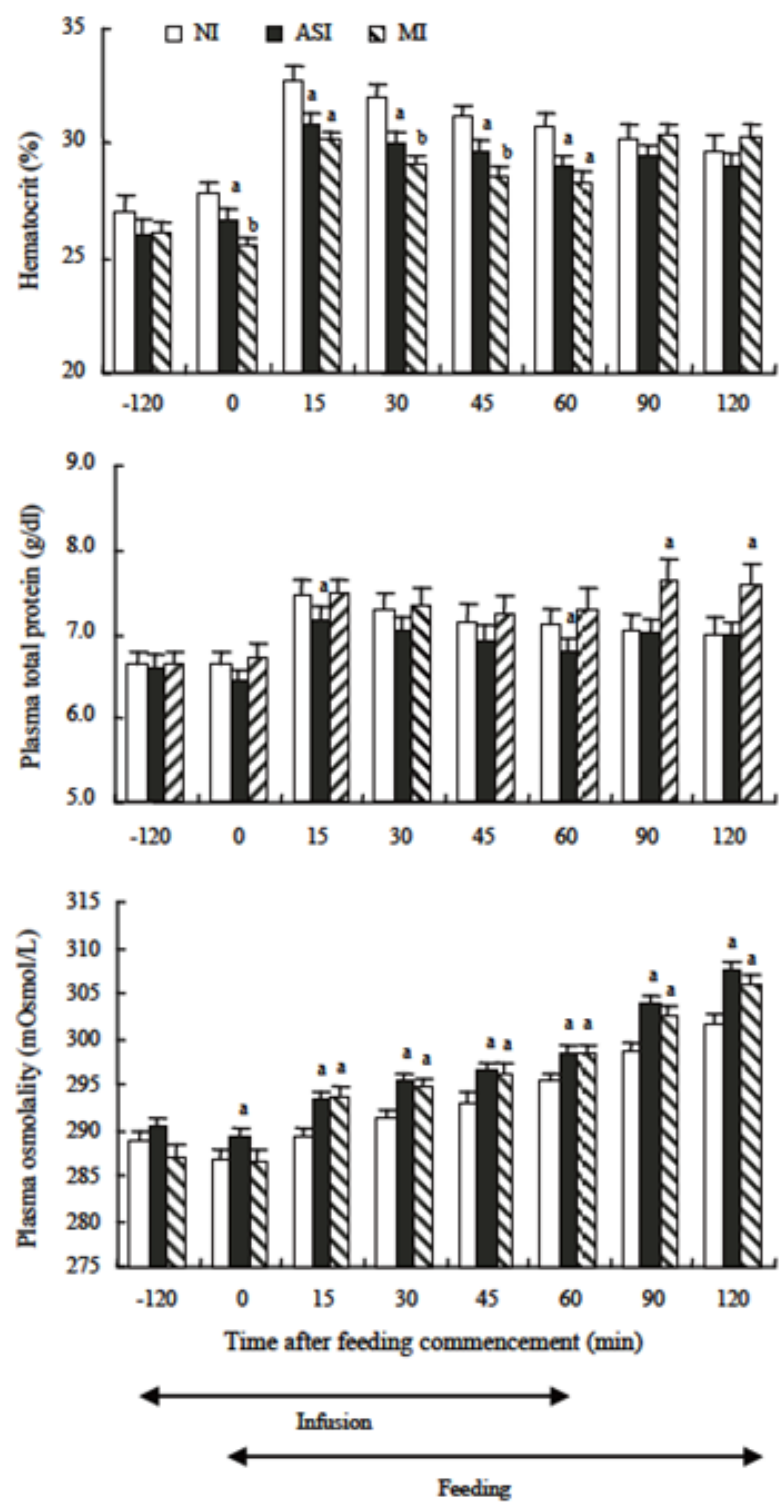

Figure 3. The effect of intravenous infusion of artificial saliva (ASI) or mannitol solution (MI) on hematocrit, plasma total protein concentration and plasma osmolality. Values are means \pm standard error of 6 large-type goats. ${ }^{\mathrm{a}, \mathrm{b}}$ Means with different superscripts differ $(\mathrm{p}<0.05)$ from the non-infusion control (NI) (Sunagawa et al., 2008). significantly lower than the NI control, plasma total protein concentrations were not different (Figure 3). From these results, it is clear that the MI treatment was less effective than the ASI treatment in mitigating the decreases in plasma volume brought about by dry forage feeding. This indicates that plasma volume increased during dry forage feeding in the ASI treatment which inhibited production of angiotensin II (ANG II) in the blood. The ASI treatment lessened the levels of suppression on dry forage feeding, but the MI treatment had no effect on it under free drinking conditions (Figure 4). The results indicate that despite the free drinking conditions, increases in saliva secretion during the initial stages of dry forage feeding in large-type goats caused $\mathrm{NaHCO}_{3}$ to be lost from the blood into the rumen which in turn caused a decrease in circulating plasma volume and resulted in activation of the renin-angiotensin system and thus feeding was suppressed. Sunagawa et al. (2007) also indicated that the suppression of saliva secretion was brought about by the loss of $\mathrm{NaHCO}_{3}$ from the blood due to increased saliva secretion during the initial stages of dry forage feeding (Figure 5). Angiotensin II is produced in the blood and vasopressin is secreted when circulating plasma volume decreases in rats and sheep (Blair-West and Brook,
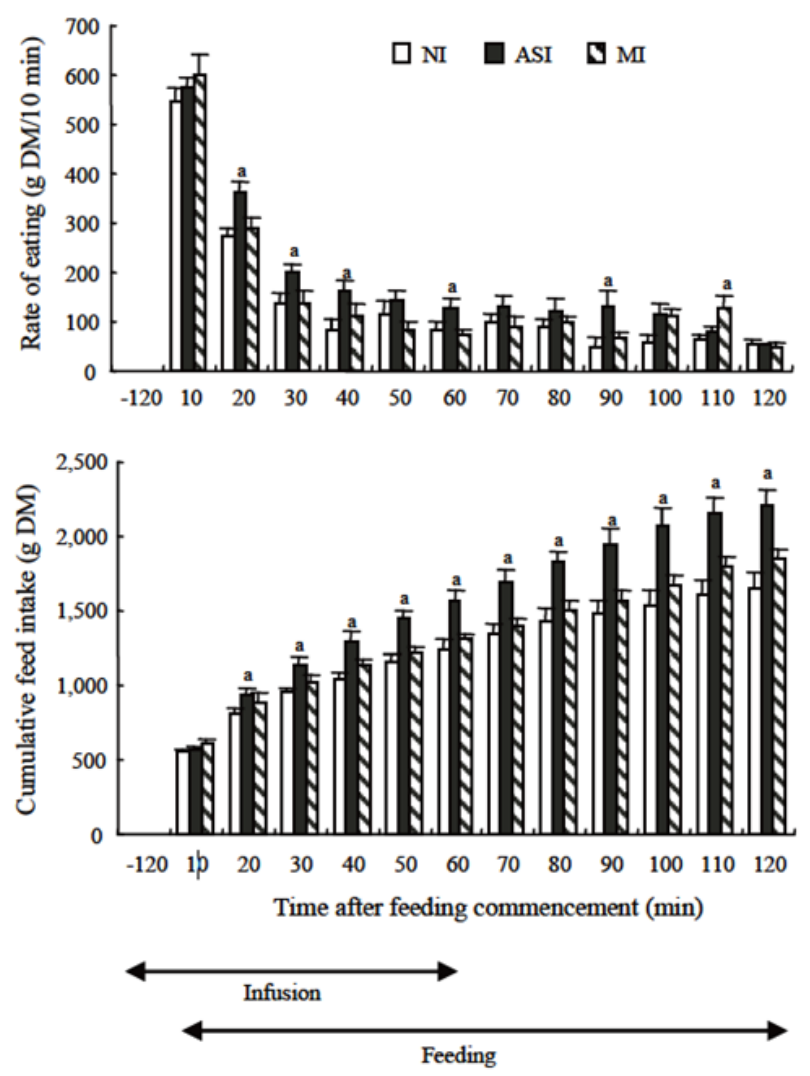

Figure 4. The effect of intravenous infusion of artificial saliva (ASI) or mannitol solution (MI) on eating rates and cumulative feed intake. Values are means \pm standard error of 6 large-type goats. ${ }^{a}$ Means with different superscripts differ $(\mathrm{p}<0.05)$ from the noninfusion control (NI) (Sunagawa et al., 2008). 

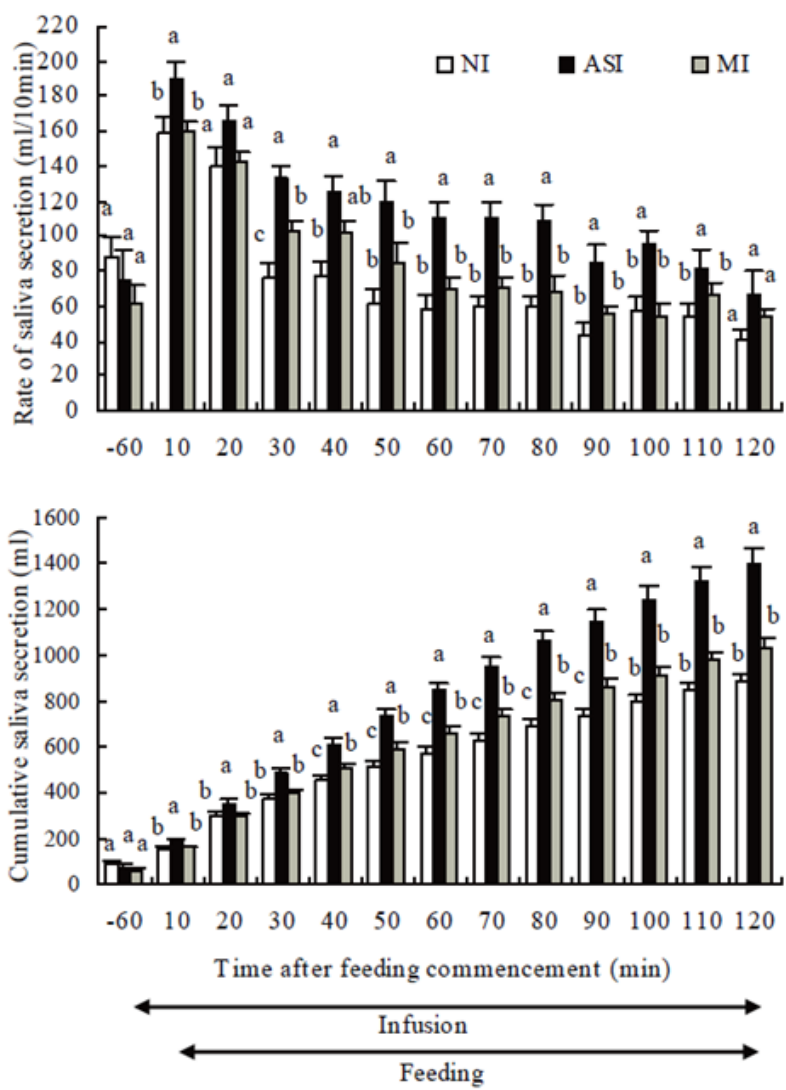

Figure 5. The effects of intravenous infusion of artificial parotid saliva (ASI) or iso-osmotic mannitol solution (MI) on rate of saliva secretion and cumulative saliva secretion. Values are means \pm standard error of 7 parotid fistulated goats. ${ }^{a, b, c}$ Means with different superscripts differ $(\mathrm{p}<0.05)$ from non-infusion control (NI) (Sunagawa et al., 2007).

1969; Fitzsimons, 1979; Mathai et al., 1997). The intravenous infusion of ANG II reduced parotid saliva secretion in ewes (McKinley et al., 1979). Sunagawa et al. (2001) reported that brain ANG II reduced dry forage intake in sheep. These facts indicate that the marked suppression of dry forage intake during the first hour was caused by a feeding-induced hypovolemia while the suppression of saliva secretion was brought about by the loss of $\mathrm{NaHCO}_{3}$ from the blood due to increased saliva secretion during the initial stages of dry forage feeding.

A physiological suppression of dry forage intake caused by salivary secretion volume related ruminal distension by excessive salivation during dry forage feeding

Ruminants consume an enormous amount of hay (lower energy content) in a short time. Saliva in large-type goats is secreted in large volume during the first hour after the commencement of dry forage feeding (Sunagawa et al., 2007). Thang et al. (2010) has found that in esophagealfistulated large-type goats fed dry forage twice daily, the amount of salivary secretion was larger than dry forage intake. Therefore, it is thought that salivary secretion volume during dry forage feeding may work in conjunction with consumed feed to form the ruminal load responsible for ruminal distension.

Campling and Balch (1961) reported that feed intake was decreased when a balloon was inserted into the rumen and inflated with water in cows fed on hay and silage. Many experiments have shown that intraruminal infusion of a sodium salts with VFA causes a decrease in dry forage intake (Forbes, 1995). On the other hand, Grovum (1995) reported that the increase in ruminal fluid osmolality by intraruminal infusion of the same dose of hyperosmotic $\mathrm{NaCl}, \mathrm{PEG}$, sodium acetate or sodium propionate resulted in the same-sized decreases in alfalfa pellet intake by sheep. However, Anil et al. (1993) reported that in cows, if a balloon inserted into the rumen was not filled with enough water or if the increase in ruminal fluid osmolality was insufficient, the amount of dry forage or silage intake was not decreased. In experiments (Campling and Balch, 1961; Anil et al., 1993) in which a balloon was inserted into the rumen and filled with water, it is unclear as to how the volume of water is determined and whether the level of ruminal distension is within the physiological range. Consequently, it is not clear whether the ruminal distension produced by feed boluses entering the rumen during dry forage feeding was a physiological suppressing factor on dry forage intake in ruminants.

Two experiments (Thang et al., 2011a) under sham feeding (SFC: feed boluses were removed from the esophageal fistula) conditions were conducted to determine whether or not ruminal distension brought about by feed boluses entering the rumen is a factor in the marked suppression of feed intake after $40 \mathrm{~min}$ of feeding. In experiment 1, a comparison was made between the intraruminal insertion of a water filled balloon (RIB) treatment and normal control (non-insertion of a balloon, NIB). The volume of water that was infused into the balloon was similar to the weight of feed boluses removed via an esophageal fistula during the $2 \mathrm{~h}$ feeding period. In experiment 2, saliva lost due to SFC was replenished via an intraruminal infusion of iso-osmotic artificial saliva. A comparison of dry forage intake was then conducted between the intraruminal replenishment of iso-osmotic artificial saliva and insertion of a balloon (RRIAS-RIB) treatment, and the intraruminal replenishment of isoosmotic artificial saliva and non-insertion of a balloon (PRIAS-NIB) control. In experiment 1, eating rates in the RIB treatment 30 min after the commencement of feeding tended to be lower than those in the NIB control. In comparison with the NIB control $(2,682.4 \pm 321.76 \mathrm{~g} / 2 \mathrm{~h})$, cumulative dry forage intake in the RIB treatment $(1,884.9 \pm 310.72 \mathrm{~g} / 2 \mathrm{~h})$ was $29.7 \%$ less $(\mathrm{p}<0.05)$ upon conclusion of the $2 \mathrm{~h}$ feeding period. The secreted saliva weight in the NIB control $(3,622.0 \pm 104.13 \mathrm{~g} / 2 \mathrm{~h})$ and the 
RIB treatment $(3,480.0 \pm 533.41 \mathrm{~g} / 2 \mathrm{~h})$ during the $2 \mathrm{~h}$ feeding period was $53.2 \%$ and $60.9 \%$ total weight of the boluses, respectively. In experiment 2 , eating rates in RRIAS-RIB treatment $30 \mathrm{~min}$ after the commencement of feeding was significantly lower $(p<0.05)$ than those in the RRIAS-NIB control. Cumulative dry forage intake in the RRIAS-RIB treatment $(1,559.6 \pm 380.43 \mathrm{~g} / 2 \mathrm{~h})$ was a significant $45.5 \%$ less $(\mathrm{p}<0.05)$ compared with that in the RRIAS-NIB control $(2,861.1 \pm 316.50 \quad \mathrm{~g} / 2$ h) upon conclusion of the $2 \mathrm{~h}$ feeding period. The secreted saliva weight in the RRIAS-NIB $(3,998.0 \pm 327.27 \mathrm{~g} / 2 \mathrm{~h})$ control and the RRAS-RIB treatment $(3,320.0 \pm 653.18 \mathrm{~g} / 2 \mathrm{~h})$ during the $2 \mathrm{~h}$ feeding period was $54.1 \%$ and $64.2 \%$ total weight of the boluses, respectively. The level of decrease in dry forage intake in the RRIAS-RIB treatment of experiment 2 was larger than that in the RIB treatment of experiment 1 . In the present experiments, due to the SFC, the increases in osmolality of ruminal fluid and plasma and a decrease in ruminal fluid $\mathrm{pH}$ which are normally associated with feeding were not observed. The results indicate that the marked decrease in feed intake observed in the second hour of the $2 \mathrm{~h}$ feeding period is related to ruminal distension caused by the feed consumed and the copious amount of saliva secreted during dry forage feeding.

A physiological suppression of dry forage intake caused by increases in plasma osmolality and subsequent thirst sensations due to dry forage feeding

It was reported that the feed intake of alfalfa pellets was regulated by changes in ruminal fluid osmolality (Baile et al., 1969; Kato et al., 1979; Grovum, 1995). The same sized dose of hyper-osmotic $\mathrm{NaCl}$, PEG, sodium acetate or sodium propionate produced the same increases in rumen fluid osmolality when intraruminally infused. These increases in rumen fluid osmolality resulted in the same sized decreases in feed intake (Grovum, 1995). On the other hand, when the ruminal fluid osmolality was decreased by the intraruminal infusion of an excessive amount of warm water $\left(39.8^{\circ} \mathrm{C}\right)$ in goats fed on roughly crushed alfalfa hay cubes, feed intake increased by 30\% (Sunagawa et al., 2002). It was thought that the changes in ruminal fluid osmolality were sensed by the osmoreceptors in the rumen wall and these signals were then transported to the central nervous system (Leek and Harding, 1975). However, osmoreceptors have not been found in the rumen wall. In addition, the effect of internal humoral factors on the intake of grass has not been investigated under these experimental conditions.

After the commencement of dry forage feeding, the copious amount of saliva secreted decreases plasma volume, and hematocrit (packed cell volume) and plasma protein concentration markedly increase. In contrast, plasma osmolality increases slowly in the first hour of a $2 \mathrm{~h}$ feeding
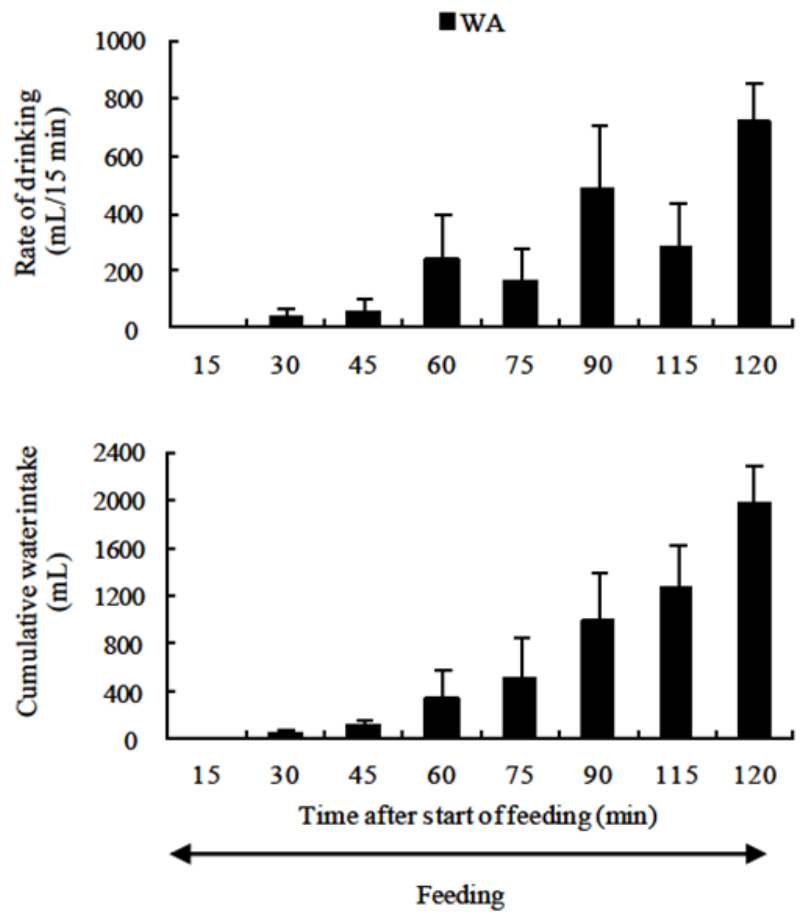

Figure 6. Rate of drinking and cumulative water intake in water availability (WA) treatment under normal feeding conditions (Thang et al., 2012b).

period and drinking frequency is extremely low (Thang et al., 2012b; Figure 6). However, plasma osmolality increased after $1 \mathrm{~h}$ of feeding due to the ruminal absorption of salt from the consumed feed. This caused a marked increase in drinking frequency (Thang et al., 2012b). Sasaki et al. (1975) reported that the increases in plasma osmolality during feeding were caused by increased salivary secretion during the initial stages of dry forage feeding period. However, the level of increases in plasma osmolality during the first hour of dry forage feeding was very small compared with that in plasma osmolality during the second hour, and drinking frequency was extremely low (Thang et al., 2012b). Sato (1975) demonstrated that decreases in parotid saliva secretion rates after dry forage feeding were related to increases in plasma osmolality. Warner and Stacy (1977) reported that there is a negative correlation between saliva secretion rates and plasma osmolality.

Thang et al. (2011b) clarified whether or not increases in plasma osmolality and subsequent thirst sensation produced by dry forage feeding suppress dry forage intake. Two experiments (Thang et al., 2011b) were conducted under SFC (removed boluses from esophageal cannula) using large-type male esophageal- and ruminal-fistulated goats. The animals were fed ad libitum a diet of roughly crushed alfalfa hay cubes for $2 \mathrm{~h}$ from 10:00 to 12:00 during two experiments. Water was withheld during feeding in both experiments but was available for a period of 30 min after completion of the $2 \mathrm{~h}$ feeding period. In 
experiment 1, an intraruminal infusion of artificial parotid saliva (RIAPS) in control replenished saliva lost via the esophageal fistula and an intraruminal infusion of hypertonic solution (RIHS) in the treatment was carried out in order to reproduce the effects of changing salt content due to feed entering the rumen. In experiment 2, the RIHS control was conducted in the same manner as the RIHS treatment of experiment 1 . The treatment group consisted of RIHS-with an intravenous infusion of artificial mixed saliva (VIAMS) treatment that was carried out for $3 \mathrm{~h}$ to prevent increases in plasma osmolality during feeding. The results of the RIHS treatment in experiment 1 showed that ruminal fluid osmolality increased and then an increase in plasma osmolality was observed. This resulted in the production of thirst sensation and the reduction of cumulative dry forage intake to $43.3 \%(p<0.05)$ of the RIAPS control. The results of the RIHS-VIAMS treatment in experiment 2 indicated that ruminal fluid osmolality was the same as the RIHS control but plasma osmolality significantly decreased, and thirst level was markedly reduced (Figures 7 and 8). This caused a significantly increase of $31.4 \% \quad(p<0.05)$ in cumulative dry forage intake in the RIHS-VIAMS treatment $(2,591.4 \pm 312.18 \mathrm{~g} / 2 \mathrm{~h})$ compared to the RIHS control $(1,972.6 \pm 359.72 \mathrm{~g} / 2 \mathrm{~h})$. These results indicate that increases
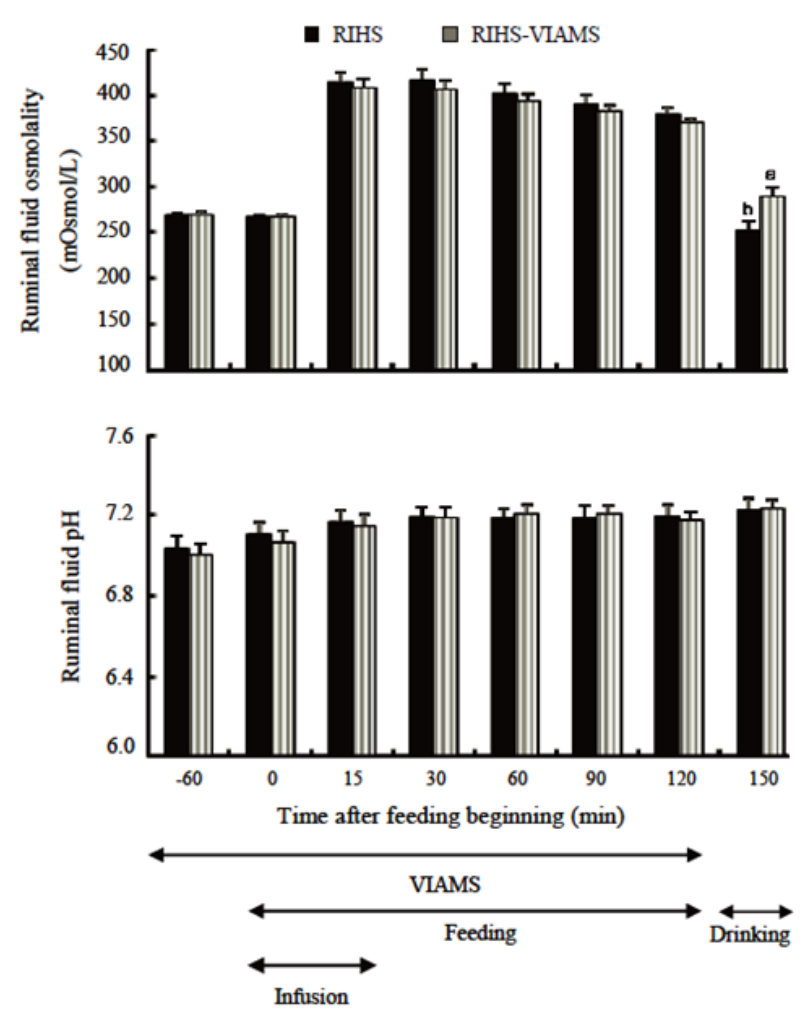

Figure 7. The effect of intraruminal infusion of hypertonic solution and intravenous infusion of artificial mixed saliva (RIHSVIAMS) on ruminal fluid osmolality and $\mathrm{pH}$. Values are means \pm standard error of 8 large-type goats. ${ }^{\mathrm{a}, \mathrm{b}}$ Means with different superscript are significantly different $(\mathrm{p}<0.05)$ from intraruminal infusion of hypertonic solution (RIHS) (Thang et al., 2011b). in ruminal fluid osmolality during dry forage feeding indirectly suppresses dry forage intake by causing an increase in plasma osmolality and subsequently inducing thirst sensations. The results of the present study suggest that marked decreases in dry forage intake after $40 \mathrm{~min}$ of feeding are caused by increases in plasma osmolality and subsequent thirst sensations produced by dry forage feeding.

\section{The main physiological suppressing factors of dry} forage intake in large-type goats

The objective of this study (Thang et al., 2012a) was to determine whether or not the marked decreases in dry forage intake after $40 \mathrm{~min}$ of feeding are mainly caused by the two factors, that is, ruminal distension and increased plasma osmolality induced thirst produced by dry forage feeding.

Six large-type male esophageal- and ruminal-fistulated goats were used in two experiments. The animals were fed
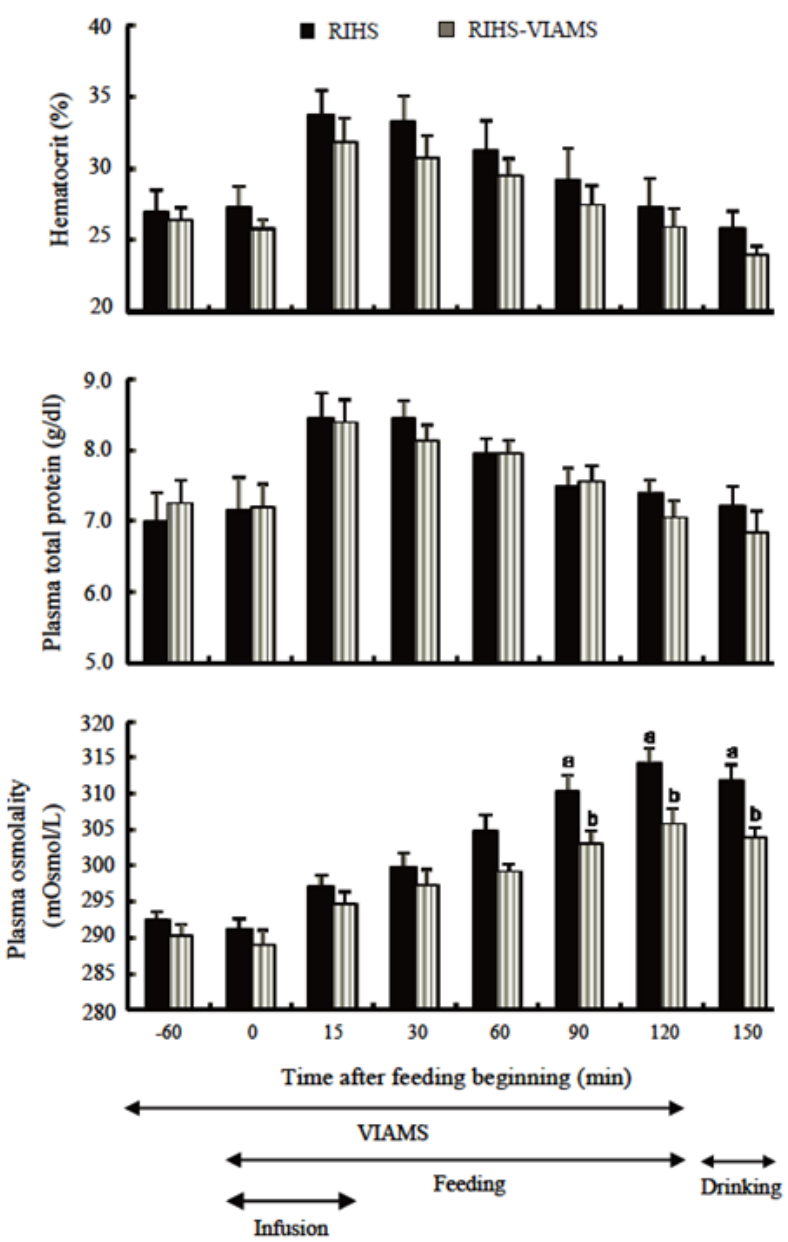

Figure 8. The effect of intraruminal infusion of hypertonic solution and intravenous infusion of artificial mixed saliva (RIHSVIAMS) on hematocrit, plasma total protein concentration and plasma osmolality. Values are means \pm standard error of 8 largetype goats. ${ }^{a, b}$ Means with different superscript are significantly different $(p<0.01)$ from intraruminal infusion of hypertonic solution (RIHS) (Thang et al., 2011b). 
ad libitum a diet of roughly crashed alfalfa hay cubes for 2 $\mathrm{h}$ from 10:00 to 12:00 am during two experiments. Water was withheld during feeding in both experiments but was available for a period of $30 \mathrm{~min}$ after completion of the $2 \mathrm{~h}$ feeding period. In experiment 1 , saliva lost via the esophageal fistula was replenished by RIAPS in a control under SFC, and the treatment was NFC (feed boluses entered into the rumen). In experiment 2, a RIAPS and noninsertion of a balloon (RIAPS-NIB) control was conducted in the same manner as the SFC control of experiment 1 . The intraruminal infusion of hypertonic solution and insertion of a balloon (RIHS-IB) treatment was carried out simultaneously to reproduce the effects of changing salt content and ruminal distension due to feed boluses entered the rumen. The results of experiments 1 showed that due to the effects of multiple dry forage suppressing factors when feed boluses entered the rumen, eating rates in the NFC treatment decreased $(\mathrm{p}<0.05)$ after $40 \mathrm{~min}$ of feeding and cumulative dry forage intake for the $2 \mathrm{~h}$ feeding period $(1,871.5 \pm 109.27 \mathrm{~g} / 2 \mathrm{~h})$ reduced to $43.8 \%$ of the SFC control $(3,332.7 \pm 270.32 \mathrm{~g} / 2 \mathrm{~h})(\mathrm{p}<0.01)$. The results of experiment 2 indicated that due to the two suppressing factors of ruminal distension and increased plasma osmolality induced thirst, eating rates in the RIHS-IB treatment were, as observed under NFC, reduced $(\mathrm{p}<0.05)$ and cumulative dry forage intake for the $2 \mathrm{~h}$ feeding period $(2,200.2 \pm 235.15 \mathrm{~g} / 2 \mathrm{~h})$ decreased to $34.0 \%$ of the RIAPSNIB control $\quad(3,332.7 \pm 270.32 \mathrm{~g} / 2 \mathrm{~h}) \quad(\mathrm{p}<0.01)$. The combined effects of ruminal distension and increased plasma osmolality accounted for $77.6 \%(=34.0 \% / 43.8 \%)$ of the suppression of dry forage intake $40 \mathrm{~min}$ after the start of dry forage feeding. The results indicate that ruminal distension and increased plasma osmolality induced thirst are the main factors in suppression of dry forage intake in large-type goats.

When goats feed on dry forage, they use saliva to form boluses in their mouths prior to swallowing. Because of this, copious amounts of saliva are used during dry forage feeding. During early stages of dry forage feeding, a large amount of saliva is necessary. Saliva secretion levels, however, decrease markedly by the 40th minute of feeding. Intravenous infusion of artificial saliva was initiated $2 \mathrm{~h}$ before feeding and was continued for a total of $3 \mathrm{~h}$ concluding $1 \mathrm{~h}$ after the commencement of feeding. This helped alleviate the dramatic decrease in salivary secretion during the initial stages of dry forage feeding. Additionally, the marked decrease in dry forage intake was also reduced. These results indicate that the decrease in feed intake during the initial stages of dry forage feeding is caused by hypovolemia and the loss of $\mathrm{NaHCO}_{3}$.

After $40 \mathrm{~min}$ of the $2 \mathrm{~h}$ dry forage feeding period, the salt from the feed is absorbed into the rumen and plasma osmolality increases. Increases in plasma osmolality suppress saliva secretion. After 40 minutes of feeding, the salivary secretion volume is low and the boluses collected via the esophageal fistula were dry and easily crumbled. Increases in plasma osmolality also increased thirst. In conjunction with this, the rumen distends due to the salivary secretion volume that occurs with feed consumption.

Large amounts of saliva are essential during dry forage feeding. However, excessive salivary secretion following dry forage feeding during the first hour tends to suppress dry forage intake due to hypovolemia and the loss of $\mathrm{NaHCO}_{3}$. During the second hour of feeding, increases in ruminal distension and plasma osmolality suppress dry forage intake.

\section{Thirst is not stimulated by hypovolemia produced during and after dry forage feeding}

Thirst sensation is created in the brain using neural and chemical signals from the peripheral stimulations (Oldfield, et al., 1994; Mckinley et al., 2004). Until now, it has been accepted that thirst is caused by any one of two factors, that is, the decreased circulating plasma volume (Stricker, 1966; Stricker et al., 1992; Fitzsimons, 1998) and the increased plasma osmolality (McKinley et al., 2004). It has not been clarified in large animals whether or not this is the case.

In the experiment (Thang et al., 2012b), dry forage and water were given to goats ad libitum. At that time, animals consumed large amounts of dry forage during the first hour for the $2 \mathrm{~h}$ feeding period, but ate small amounts of feed during the second hour (Figure 4). As opposed to feeding, animals drank small amounts of water during first hour, but large amounts of water during second hour (Figure 6). In early stages of dry forage feeding, in order to eat large amounts of dry forage, a large amount of saliva is secreted. This resulted in disturbance of body fluid homeostasis. The circulating plasma volume, urine volume and blood $\mathrm{pH}$ decrease, and ADH level increases (Blair-West and Brook, 1969; Sasaki et al., 1974). The marked increases in hematocrit and total plasma protein concentration in early stages of dry forage feeding indicate decrease in circulating plasma volume. Although circulating plasma volume decreases in the early stages of dry forage feeding, animals are not thirsty (Figure 6).

The objective of this study (Thang et al., 2012b) was to clarify which factor produced when feed boluses enter the rumen is mainly responsible for the marked increase in water intake in the second hour of the $2 \mathrm{~h}$ feeding period in large-type goats fed on dry forage for $2 \mathrm{~h}$ twice daily. Six large-type male esophageal- and ruminal fistulated goats were used in two experiments. In experiment 1, the water deprivation control and the water availability (WA) treatment were conducted to compare changes in water intake during and after dry forage feeding. In experiment 2, a normal feeding (NFC) control and a feed bolus removal 
Table 1. The effect of feed bolus removal during dry forage feeding on hematocrit, plasma concentrations of total protein, glucose, Na, $\mathrm{K}$, and $\mathrm{Cl}$ (Thang et al., 2012b)

\begin{tabular}{|c|c|c|c|c|c|c|c|c|c|c|c|c|c|c|c|c|c|c|}
\hline \multirow{2}{*}{$\begin{array}{l}\text { Time before } \\
\text { and after } \\
\text { start of } \\
\text { feeding } \\
\text { (min) }\end{array}$} & \multicolumn{3}{|c|}{ Hematocrit (\%) } & \multicolumn{3}{|c|}{$\begin{array}{l}\text { Plasma total protein } \\
(\mathrm{g} / \mathrm{dL})\end{array}$} & \multicolumn{3}{|c|}{$\begin{array}{c}\text { Plasma glucose } \\
(\mathrm{mg} / \mathrm{dL})\end{array}$} & \multicolumn{3}{|c|}{$\begin{array}{c}\text { Plasma Na } \\
(\mathrm{mmol} / \mathrm{L})\end{array}$} & \multicolumn{3}{|c|}{$\begin{array}{l}\text { Plasma K } \\
(\mathrm{mmol} / \mathrm{L})\end{array}$} & \multicolumn{3}{|c|}{$\begin{array}{l}\text { Plasma Cl } \\
(\mathrm{mmol} / \mathrm{L})\end{array}$} \\
\hline & $\mathrm{NFC}$ & FBR & SE & $\mathrm{NFC}$ & FBR & SE & $\mathrm{NFC}$ & FBR & $\mathrm{SE}$ & $\mathrm{NFC}$ & FBR & SE & $\mathrm{NFC}$ & FBR & SE & NFC & FBR & SE \\
\hline-60 & 25.3 & 25.9 & 1.22 & 6.8 & 7.1 & 0.30 & 71.5 & 66.0 & 3.22 & $138.7^{\mathrm{b}}$ & $140.8^{\mathrm{a}}$ & 1.07 & 4.6 & 4.6 & 0.23 & 100.0 & 101.0 & 1.21 \\
\hline 0 & 25.2 & 26.1 & 1.29 & 6.8 & 7.1 & 0.31 & $69.3^{\mathrm{a}}$ & $66.2^{\mathrm{b}}$ & 2.10 & $137.8^{\mathrm{b}}$ & $140.5^{\mathrm{a}}$ & 0.90 & 4.6 & 4.7 & 0.17 & $99.5^{b}$ & $100.3^{\mathrm{a}}$ & 0.75 \\
\hline 15 & 31.1 & 33.8 & 1.76 & $7.8^{\mathrm{b}}$ & $8.4^{\mathrm{a}}$ & 0.42 & 70.5 & 67.5 & 3.28 & 139.2 & 141.3 & 1.10 & 4.7 & 4.8 & 0.15 & 104.2 & 104.8 & 0.96 \\
\hline 30 & 30.6 & 34.3 & 1.98 & $7.6^{\mathrm{b}}$ & $8.6^{\mathrm{a}}$ & 0.41 & 68.3 & 66.3 & 2.74 & $139.3^{\mathrm{b}}$ & $140.8^{\mathrm{a}}$ & 1.69 & 4.6 & 4.7 & 0.19 & 105.7 & 105.0 & 1.74 \\
\hline 60 & $29.0^{\mathrm{b}}$ & $34.0^{\mathrm{a}}$ & 1.68 & $7.4^{\mathrm{b}}$ & $8.6^{\mathrm{a}}$ & 0.35 & 68.8 & 65.5 & 2.58 & 142.8 & 141.8 & 1.18 & 4.8 & 4.7 & 0.20 & 105.8 & 105.7 & 1.07 \\
\hline 90 & $28.6^{\mathrm{b}}$ & $34.3^{\mathrm{a}}$ & 1.72 & $7.2^{\mathrm{b}}$ & $8.6^{\mathrm{a}}$ & 0.35 & 70.5 & 68.2 & 3.85 & $143.7^{\mathrm{a}}$ & $140.8^{\mathrm{b}}$ & 1.73 & 4.9 & 4.8 & 0.19 & 106.7 & 105.7 & 1.66 \\
\hline 120 & $28.8^{\mathrm{b}}$ & $34.5^{\mathrm{a}}$ & 2.10 & $7.3^{\mathrm{b}}$ & $8.7^{\mathrm{a}}$ & 0.33 & $72.8^{\mathrm{a}}$ & $65.7^{\mathrm{b}}$ & 3.98 & $146.8^{\mathrm{a}}$ & $142.2^{\mathrm{b}}$ & 1.67 & 4.6 & 4.8 & 0.20 & $108.7^{\mathrm{a}}$ & $105.3^{\mathrm{b}}$ & 1.22 \\
\hline 150 & 27.0 & 29.6 & 1.76 & $7.0^{\mathrm{b}}$ & $7.9^{\mathrm{a}}$ & 0.40 & 71.7 & 68.3 & 3.63 & $144.8^{\mathrm{a}}$ & $140.7^{b}$ & 1.29 & 4.5 & 4.7 & 0.20 & $105.8^{\mathrm{a}}$ & $102.0^{\mathrm{b}}$ & 1.08 \\
\hline
\end{tabular}

NFC, normal feeding conditions; FBR, feed bolus removal; SE, pooled standard error.

Values are means of 6 large-type goats.

${ }^{a, b}$ Means in the same row bearing different superscripts differ $(\mathrm{p}<0.05)$.

(FBR) treatment were carried out to investigate whether decrease in circulating plasma volume or increase in plasma osmolality is mainly responsible for the marked increase in water intake in the second hour of the $2 \mathrm{~h}$ feeding period. The results of experiment 1 showed that in the WA treatment, small amounts of water were consumed during the first hour of feeding while the majority of water intake
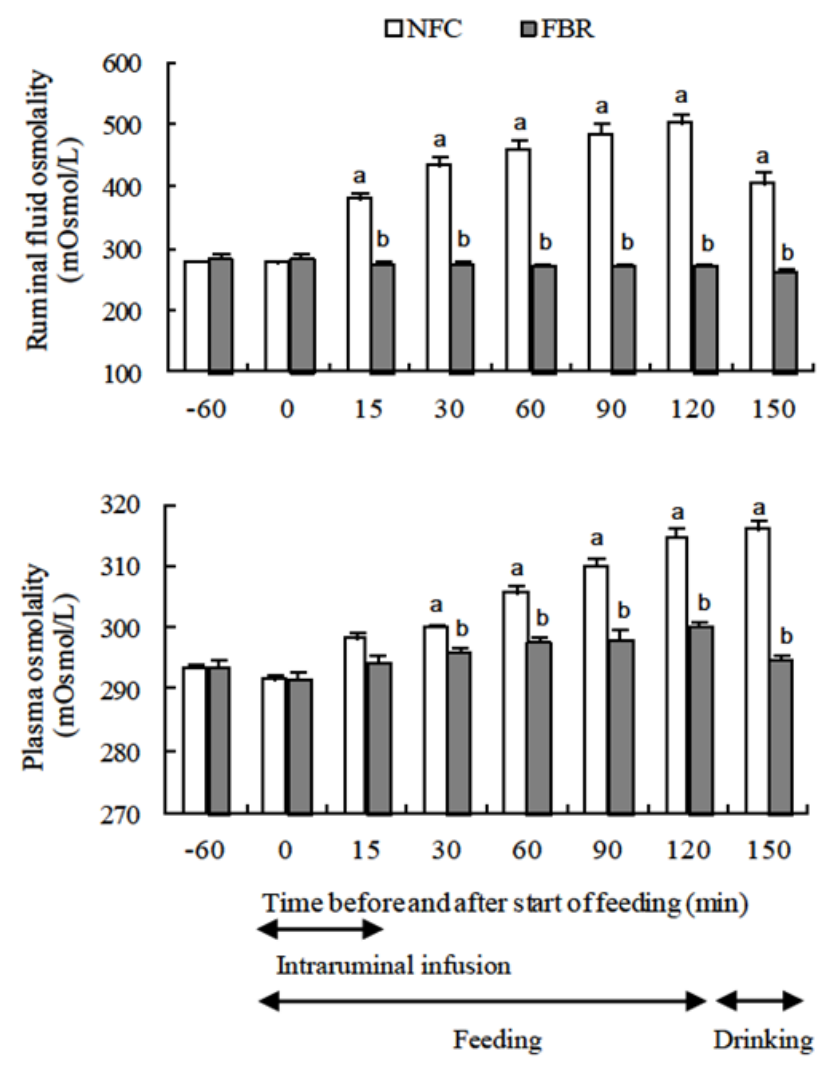

Figure 9. The effect of feed bolus removal (FBR) during dry forage feeding on osmolality of plasma and ruminal fluid. Values are means \pm standard error of 6 large-type goats. ${ }^{\text {a,b }}$ Means with different superscript are significantly different $(p<0.05)$ from normal feeding conditions (NFC) (Thang et al., 2012b). was observed during the second hour of the $2 \mathrm{~h}$ feeding period. Therefore, the amounts of water consumed in the second hour of the $2 \mathrm{~h}$ feeding period accounted for $82.8 \%$ of the total water intake (Figure 6). The results of experiment 2 indicated that in comparison with the NFC control, decrease in plasma volume in the FBR treatment, which was indicated by increase in hematocrit and plasma total protein concentration, was higher $(p<0.05)$ in the second hour of the $2 \mathrm{~h}$ feeding period (Table 1). However, plasma osmolality in the FBR treatment was lower $(p<0.05)$ than compared to the NFC control from $30 \mathrm{~min}$ after the start of feeding (Figure 9). Therefore, thirst level in the FBR treatment was $82.7 \%$ less $(\mathrm{p}<0.01)$ compared with that in the NFC control upon conclusion of the 30 min drinking period (Figure 10). The results of the study indicate that the increased plasma osmolality in the second hour of the $2 \mathrm{~h}$ feeding period is the main physiological stimulating factor of water intake during and after dry forage feeding in largetype goats.

Ciura and Bourque (2006) reported that neural cells

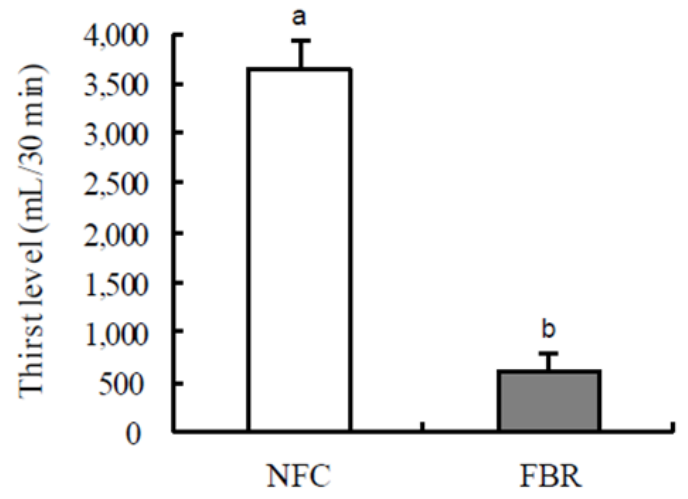

Figure 10. The effect of feed bolus removal (FBR) during dry forage feeding on thirst level. Values are means \pm standard error of 6 large-type goats. ${ }^{\text {a,b }}$ Means with different superscript are significantly different $(\mathrm{p}<0.01)$ from normal feeding conditions (NFC) (Thang et al., 2012b). 
sensitive to increases in osmolality of extracellular fluid exist in the organum vasculosum lamina terminalis (OVLT) in the anteroventral wall of the third ventricule in mice. Oldfield et al. (1994) reported that the populations of neurons in the OVLT, the subfornical organ, and median preoptic nucleus $(\mathrm{MnPO})$ in the lamina terminalis are activated by intravenous infusion of either hypertonic saline or ANG II. Sunagawa et al. (2001) reported that in sheep fed on dry alfalfa chaff once a day, an intracerebroventricular infusion of ANG II induced thirst sensations and reduced dry forage intake. Mathai et al. (1977) reported that in sheep fed oaten-lucerne chaff, intracerebroventricular infusion of the $\mathrm{AT}_{1}$ type $\mathrm{ANG}$ II receptor blocker losartan reduced postprandial drinking. These reports support the present results that increased water intake in the second hour of the $2 \mathrm{~h}$ feeding period in large-type goats fed on dry forage for $2 \mathrm{~h}$ twice daily is the result of increases in plasma osmolality, caused by the ruminal absorption of salts from the consumed feed, that in turn bypassed the blood-brain barrier and activated the osmosenstive neurons in the circumventricular organs.

During the second hour of dry forage feeding period, thirst sensations occur and frequent drinking behavior is observed. The cause of this is not hypovolemia brought about by excessive salivation, but rather increases in plasma osmolality that is caused when the salt from consumed feed is absorbed by the rumen. This suggests the water intake following dry forage feeding is determined by the level of salt content in the feed.

\section{CONCLUSIONS}

The results indicate that ruminal distension and increased plasma osmolality induced thirst are the main factors in suppression of dry forage intake in large-type goats. In addition, thirst is not stimulated by a decrease in circulating plasma volume (hypovolemia) but rather by an increase in plasma osmolality caused by dry forage feeding. Thirst level is determined by salt content in food. The review advances knowledge on controlling mechanisms of dry forage intake in domestic ruminants. Such information is an essential requirement in the development of methods to improve management, welfare and performance.

\section{CONFLICT OF INTEREST}

We certify that there is no conflict of interest with any financial organization regarding the material discussed in the manuscript.

\section{ACKNOWLEDGMENTS}

We thank Mr. Glenn McIlvride for his English proof- reading on this manuscript. The computation was mainly carried out using the computer facilities in the Research Institute for Information Technology, Kyushu University.

\section{REFERENCES}

Annison, E. F. and D. G. Armstrong. 1970. Volatile fatty acid metabolism and energy supply. In: Physiology of Digestion and Metabolism in Ruminants. Proceeding of the 3rd International Symposium (Ed. A. T. Phillipson). Oriel Press, Newcastle upon Tyne, UK. pp. 422-437.

Anil, M. H., J. N. Mbanya, H. W. Symonds, and J. M. Forbes. 1993. Responses in the voluntary intake of hay or silage by lactating cows to intraruminal infusions of sodium acetate or sodium propionate, the tonicity of rumen fluid or rumen distension. Br. J. Nutr. 69:699-712.

Argenzio, R. 1984. Secretory function of the gastrointestinal tract. In: Dukes' Physiology of Domestic Animals (Ed. M. J. Swenson). Cornell University Press, New York, USA. 292 p.

Bail, C. A. and J. M. Forbes. 1974. Control of feed intake and regulation of energy balance in ruminants. Physiol. Rev. 54:160-214.

Baile, C. A., J. Mayer, and C. L. McLaughlin. 1969. Feeding behavior of goats: Ruminal distension, ingesta dilution, and acetate concentration. Am. J. Physiol. 217:397-402.

Blair-West, J. R. and A. H. Brook. 1969. Circulatory changes and renin secretion in sheep in response to feeding. J. Physiol. 204:15-30.

Campling, R. C. and C. C. Balch. 1961. Factors affecting the voluntary feed intake of the cow. 1. Preliminary observations on the effect, on the voluntary intake of hay, of changes in the amount of the reticulo-ruminal contents. Br. J. Nutr. 15:523530.

Ciura, S. and C. W. Bourque. 2006. Transient receptor potential vanilloid 1 is required for intrinsic osmoreception in organum vasculosum lamina terminalis neurons and for normal thirst responses to systemic hyperosmolality. J. Neurosci. 26:90699075.

Denton, D. A. 1982. The sheep (a ruminant) as a felicitous creature for research in experimental endocrinology and blood fluid regulation: Control of aldosterone secretion. In: The Hunger for Salt (Ed. D. A. Denton). Springer-Verlag. New York, NY, USA. pp. 145-167.

Fitzsimons, J. T. 1979. The physiology of thirst and sodium appetite. Cambridge University Press, Cambridge, UK. 59 p.

Fitzsimons, J. T. 1998. Angiotensin, thirst, and sodium appetite. Physiol. Rev. 78:583-686.

Forbes, J. M. 1995. Ruminant gastrointestinal tract. In: Voluntary food intake and diet selection in farm animals (Ed. J. M. Forbes). CAB International, Wallingford, UK. pp. 58-80.

Grovum, W. L. 1995. Mechanisms explaining the effects of short chain fatty acids on feed intake in ruminants-osmotic pressure, insulin and glucose. In: Ruminant physiology: Digestion, Metablism, Growth and Reproduction. Proceedings of the Eight International Symposium on Ruminant Physiology (Eds. W. V. Engelhardt, S. Leonhard-Marek, G. Breves, and D. Giesecke). Ferdinant Enke Verlag, Stuttgart, Germany. pp. 173-197. 
Hidari, H. 1981. The relationships between rumen load and diurnal eating pattern of sheep fed in various time of access to feed. Jpn J. Zootech. Sci. 52:219-226.

Kato, S., Y. Sasaki, and T. Tsuda. 1979. Food intake and rumen osmolality in the sheep. Annales de Recherches Veterinaire 10:229-230.

Leek, B. F. and R. H. Harding. 1975. Sensory nervous receptors in the ruminant stomach and the reflex control of reticulo-ruminal motility. In: Digestion and Metabolism in the Ruminant Stomach (Eds. I. W. McDonald and A. C. I. Warner). University of New England Publishing Unit, Armidale, Australia. pp. 60-76.

Liu, J. R., B. Yu, F. H. Liu, K. J. Cheng, and X. Zhao. 2005. Expression of rumen microbial fibrolytic enzyme genes in probiotic Lactobacillus reuteri. Appl. Environ. Microbiol. 71:6769-6775.

Mathai, M., M. D. Evered, and M. J. McKinley. 1997. Intracerebroventricular losartan inhibits postprandial drinking in sheep. Am. J. Physiol. 272:R1055-R1059.

McKinley, M. J., M. J. Cairns, D. A. Denton, G. Egan, M. L. Mathai, A. Uschakov, J. D. Wade, R. S. Weisinger, and B. J. Oldfield. 2004. Physiological and pathological influences on thirst. Physiol. Behav. 81:795-803.

McKinley, M. J., D. A. Denton, S. Hatzikostas, and R. S. Weisinger. 1979. Effect of angiotensin II on parotid saliva secretion in conscious sheep. Am. J. Physiol. 237:E56-E60.

Nagamine, I., K. Sunagawa, J. Kuriwaki, and A. Shinjo. 2003. Chnages in single unit activity in the lateral hypothalamic area of goats during feeding. J. Anim. Sci. 81:529-536.

Oldfield, B. J., E. Bader, D. K. Hards, and M. J. McKinley. 1994. Fos production in retrogradely labelled neurons of the lamina terminalis following intravenous infusion of either hypertonic saline or angiotensin II. Neurosci 60:255-262.

Oshio, S. and I. Tahata. 1984. Absorption of dissociated volatile fatty acids through the rumen wall of sheep. Can. J. Anim. Sci. 64(Suppl.):167-168.

Sasaki, Y., S. Watanabe, Y. Sato, and S. Kato. 1974. Changes in acid-base status of sheep during eating. Jap. J. Zootech. Sci. 45:8-13.

Sasaki, Y., S. Watanabe, Y. Sato, and S. Kato. 1975. Changes in renal excretion of minerals after feeding in sheep. Jap. J. Zootech. Sci. 46:208-212.

Sasaki, Y., S. Watanabe, Y. Sato, and S. Kato. 1975. Effect of intravenous infusion of artificial saliva on changes in acid-base status of sheep during eating. Jap. J. Zootech. Sci. 46:449-453.

Sato, Y. 1975. The relationship between saliva secretion and body fluid balance during feeding in sheep. Ph. D. Thesis, Tohoku University, Sendai, Japan.
Stacy, B. D. and A. C. Warner. 1966. Balances of water and sodium in the rumen during feeding: Osmotic stimulation of sodium absorption in the sheep. Q. J. Exp. Physiol. 51:79-93.

Stricker, E. M. 1966. Extracellular fluid volume and thirst. Am. J. Physiol. 211:232-238.

Stricker, E. M., K. S. Gannon, and J. C. Smith. 1992. Thirst and salt appetite induced by hypovolemia in rats: analysis of drinking behavior. Physiol. Behav. 51:27-37.

Sunagawa, K., Y. Nakatsu, Y. Nishikubo, T. Ooshiro, K. Naitou, and I. Nagamine. 2002. Effects of intraruminal saliva flow on feed intake in goats fed on alfalfa hay cubes. Asian Australas. J. Anim. Sci. 15:1738-1746.

Sunagawa, K., Y. Nakatsu, Y. Nishikubo, T. Ooshiro, K. Naitou, and I. Nagamine. 2003. Effect of parotid saliva secretion on dry forage intake in goats. Asian Australas. J. Anim. Sci. 16:1118-11125.

Sunagawa, K., T. Hashimoto, M. Izuno, N. Hashizume, M. Okano, I. Nagamine, and T. Hirata. 2008. An intravenous replenishment of salivary components and dry forage intake in freely drinking large-type goats. Asian Australas. J. Anim. Sci. 21:538-546.

Sunagawa, K., T. Ooshiro, N. Nakamura, Y. Ishii, I. Nagamine, and A. Shinjo. 2007. Physiological factors depressing feed intake and saliva secretion in goats fed on dry forage. Asian Australas. J. Anim. Sci. 20:60-69.

Sunagawa, K., R. S. Weisinger, M. J. McKinley, B. S. Purcell, C. Thomson, and P. L. Burns. 2001. The role of angiotensin II in the central regulation of feed intake in sheep. Can. J. Anim. Sci. $81: 215-221$.

Thang, T. V., K. Sunagawa, I. Nagamine, and S. Kato. 2010. Deprivation of esophageal boluses and dry forage intake in large-type goats. Asian Australas. J. Anim. Sci. 23:1174-1183.

Thang, T. V., K. Sunagawa, I. Nagamine, S. Kato, and G. Ogura. 2011a. Salivary secretion volume related ruminal distension and suppression of dry forage intake in large-type goats. Asian Australas. J. Anim. Sci. 24:1100-1111.

Thang, T. V., K. Sunagawa, I. Nagamine, and G. Ogura. 2011 b. Plasma osmolality controls dry forage intake in large-type goats. Asian Australas. J. Anim. Sci. 24:1069-1085.

Thang, T. V., K. Sunagawa, I. Nagamine, T. Kishi, and G. Ogura. 2012a. The main suppressing factors of dry forage intake in large-type goats. Asian Australas. J. Anim. Sci. 25:341-352.

Thang, T. V., K. Sunagawa, I. Nagamine, T. Kishi, and G. Ogura. 2012b. A physiological stimulating factor of water intake during and after dry forage feeding in large-type goats. Asian Australas. J. Anim. Sci. 25:502-514.

Warner, A. C. I. and B. D. Stacy. 1977. Influence of ruminal and plasma osmotic pressure on salivary secretion in sheep. Q. J. Exp. Physiol. 62:133-142. 